punto org

General Editor Luigi Maria Sicca

27 


\title{
LGBT+ PERSPECTIVES
}

The University of Essex Reader

\author{
edited by \\ Ilaria Boncori
}

Editoriale Scientifica

Napoli 
All rights reserved

(c) Copyright 2017 Editoriale Scientifica s.r.l.

Via San Biagio dei Librai, 39 - 80138 Napoli

www.editorialescientifica.com info@editorialescientifica.com

ISBN 978-88-9391-045-3 


\section{Contents}

9 Foreword

Anthony Forster

11 Editor's Preface

Ilaria Boncori

\section{Part I. People and Relationships}

21 1. Being Transgender: A personal and research-based perspective

Jamie Raines

39 2. From heterosexual to same-sex relationship: A lived experience

Alison J. Taylor-Lamb

53 3. Domestic violence and abuse in Lesbian, Gay, Bisexual and Transgender (LGBT) relationships

Thomas J. Currid and Carl Chandra

71 4. Being unaware of being aware: Learning and working in two cultures

Martin Harrison and Peter J. Martin

\section{Part II. Historical perspectives}

93 5. The Pink Triangle: The Nazi persecution of gay men Rainer Schulze

107 6. The Long Shadow of the Pink Triangle after 1945 and its importance for the LGBTI movement Rainer Schulze 
Part III. Wellbeing and Discrimination

123 7. The importance of voice and communication in gender transitions

Fleur Jeans and Teresa Eade

141 8. Gender nonconformity: The impact on individual wellbeing

Tuesday Watts

157 9. The basics of Economic Theory and evidence on sexual orientation discrimination

Amy Anderson

171 10. LGBT+ experiences of sport in educational settings

Scott Lawley and Ilaria Boncori

191 INDEX

199 punto org book series 


\section{Foreword}

I am delighted to write this foreword for a number of reasons. First and foremost, this innovative volume attempts to address a wide range of very important issues that deserve attention. Second, it provides an inter-generational perspective from people at different stages of their life, opening up new lines of enquiry, observations and argument. This volume contains powerful insights from personal experiences that deserve to be read by a very wide audience. Finally, it also offers an interdisciplinary approach addressing people and relationships, historical perspectives, well-being, and discrimination. This is exactly what such an important set of issues deserves if we are to make progress in thought and action - and which is so badly needed in all the areas covered.

The University of Essex is fully committed to promoting equality and diversity. Our progress has been recognised in Stonewall's Gay by Degree 2015. We are delighted to be named as one of Britain's most inclusive employers for lesbian, gay and bisexual staff and are ranked 53 ${ }^{\text {rd }}$ in Stonewall's 2016 Workplace Equality Index. Additionally, we are the winner of Advancing Staff Equality award in the Guardian Universities' Awards 2015. What this volume underscores to me is that we have much to learn so that we can further develop our organisation culture, to ensure everyone is accepted without exception - and that our diversity lies at the very heart of being an inspirational living and learning community.

Professor Anthony Forster

Vice-Chancellor

University of Essex 